\title{
Study of cancer incidence among 6363 male workers in four Norwegian ferromanganese and silicomanganese producing plants
}

\author{
Ånund Hobbesland, Helge Kjuus, Dag S Thelle
}

\begin{abstract}
Objectives-Little has been known about the risk of cancer associated with occupational exposure to manganese. The objective of this study was therefore to examine the associations between duration of specific work and cancer incidence among employees in four Norwegian ferromanganese and silicomanganese producing plants.

Methods-Among men first employed in 1933-91 and with at least 6 months in these plants, the incident cases of cancer during 1953-91 were obtained from The Cancer Registry of Norway. The numbers of various cancers were compared with expected figures calculated from age and calendar time specific rates for Norwegian men during the same period. Internal comparisons of rates were performed with Poisson regression analysis. The final cohort comprised 6363 men.
\end{abstract}

Results-A total of 607 cases of cancer were observed against 596 cases expected (standardised incidence ratio (SIR) 1.02). Internal comparisons of rates showed a positive trend between the rate of all cancers and duration of furnace work. A slightly weaker trend was also found for duration of blue collar non-furnace work when lags of 25 or 30 years were applied in the analyses. However, several results indicated that the incidence of all cancers among the non-furnace workers decreased during the period of active employment.

Conclusions-Furnace and non-furnace workers may have exposures that increase the incidence of several cancers. The low incidence of cancer among non-furnace workers during the period of ongoing exposure cannot be explained. As this study cannot identify any causal factors, the role of exposure to manganese remains unclear.

(Occup Environ Med 1999;56:618-624)

Keywords: cancer; ferroalloy; manganese

In a previous study we found a borderline increased mortality from all cancers among men with at least 3 years of furnace work in four Norwegian ferromanganese (FeMn) and silicomanganese $(\mathrm{SiMn})$ producing plants (standardised mortality ratio (SMR) 1.19, 95\% confidence interval ( $95 \% \mathrm{CI}$ ) 0.99 to 1.42$){ }^{1}$ The mortality of specific cancers was not examined. To our knowledge only one previous occupational study of cancer incidence has included workers exposed to manganese. ${ }^{2}$ Among employees in three of the same FeMn/ SiMn plants as in the present study the overall SIRs were then $<1.00$ in all plants.

Workers in FeMn/SiMn plants were exposed to asbestos until 1982 and to various dusts from the crude materials (mainly coke, coal, manganese ore, and crystalline silica) and from the manufactured manganese alloys. An increased risk of lung cancer might be expected due to exposure to carcinogenic substances such as asbestos and crystalline silica. ${ }^{34}$ It has been previously reported that adequate data are lacking on risk of cancer from exposure to manganese..$^{5-7}$ Population studies have indicated an increased risk of lung and prostate cancer associated with exposure to manganese. ${ }^{89}$ But an inverse relation between ingestion of manganese and the incidence of cancer has also been suggested. ${ }^{10}$

Due to our previous results and the general lack of studies in this field, we have proceeded with a study of cancer incidence among workers in the four $\mathrm{FeMn} / \mathrm{SiMn}$ plants. The aim of the study was to examine the associations between duration of work and cancer incidence among employees in these plants. We also wanted to examine if there was any indication of a reduced risk of cancer during ongoing exposure. The study was performed as a historical cohort study.

\section{Materials and methods}

STUDY SETTING

The four plants are all located in the southern part of Norway. Three of the plants began manufacturing FeMn and SiMn in 1920-30 whereas the fourth plant started production in 1974. One of the old plants was shut down in 1987. The alloys have been manufactured by an electrometallurgical process where oxides of manganese and iron in manganese ore (in FeMn manufacturing) and crystalline silica (in SiMn manufacturing) are reduced by heating and by a chemical reaction between oxygen and carbon in coke and coal. A minor supply of iron as iron pellets or scrap metal has also occurred. During the past years the manufactured FeMn has mainly been composed (by weight) of $76 \%-82 \%$ manganese, $13 \%-17 \%$ iron, and $1 \%-7 \%$ carbon. The corresponding figures for $\mathrm{SiMn}$ are $65 \%-70 \%$ manganese, $10 \%-15 \%$ iron, and $17 \%-20 \%$ silicon.

Manganese is thus the main component of these alloys. 
EXPOSURE INFORMATION

Information on exposure factors is sparse. Measurements of exposure to manganese were not available in two of the four plants and no measurement of dust exposure was performed before 1974. Quantitative exposure estimation was therefore not attempted. In the largest of these plants exposure to total manganese among the furnace workers could be estimated from 339 personal samples obtained during 1979-91. ${ }^{11}$ The median value of total exposure to manganese was $0.99 \mathrm{mg} / \mathrm{m}^{3}$. The manganese ore contains $\mathrm{MnO}, \mathrm{MnO}_{2}$, a small percentage of $\mathrm{Fe}_{2} \mathrm{O}_{3}$, and small amounts of other metal oxides. By weight the most important are $\mathrm{CaO}$, $\mathrm{MgO}, \mathrm{Al}_{2} \mathrm{O}_{3}$, and $\mathrm{SiO}_{2}$. Only trace amounts of nickel and cadmium $(\leqslant 0.01 \%)$ have been detected in manganese ore. In an ongoing study of exposure in these plants no exposure to arsenic could be detected in the dust analyses (S Hetland, personal communication). However, manganese ore has been delivered to these plants from various parts of the world in 1933-91. Thus, other compositions of the ore may have occurred. As well as the manufacturing of manganese alloys which for all the four plants have been the main products, the three old plants have simultaneously produced other metals for a shorter or longer time during 1933-91. Ferrosilicon is the most important of these products. No exposure information was available for these kinds of production.

STUDY POPULATION

The cohort consisted of 6363 men employed for at least 6 months and first employed in these plants in 1933-91. The numbers of men from each of the four plants were 2636, 1823, 1438, and 466. Employment records from the plants were the main source of individual information on employment. Variables recorded were employee's name, date of birth, the five digit personal number, up to 10 employment periods with location of work, and smoking habits when available from medical records. Vital status was obtained for each subject from the records of the official population register. In Norway, people who died or emigrated before 1960 are lacking the five digit personal number. The vital data for these men were individually sought by name and date of birth.

Details of cancer cases diagnosed in the period 1953-91 were obtained from the Cancer Registry of Norway which also made available the individual dates of death from Statistics Norway (the national register for causes of death). Cases of cancer during this period were coded according to the seventh version of the international classification of diseases (ICD-7). Each man was followed up from the beginning of 1953 or if he was hired later from the first day of employment. The observation period continued until the date of death, emigration, the occurrence of two primary cancers (in the analyses of total cancer), or the end date of the study. A total of 158 men $(2 \%$ of the primary male cohort of 7256 men) were excluded due to unknown vital data or deaths before 1953. Men first employed before 1933 (735) were excluded. Nine cases of cancer which had occurred in 1953 or later but before the start of employment in this industry were omitted, but the men were followed up for a second cancer. The cohort was studied for 153565 person-years. The median duration of employment was 5.7 years. The median age at start of first employment and end of last employment was 24.8 and 36.5 years, respectively. The median duration of follow up was 24.2 years. In total, 4124 men $(65 \%)$ had worked for at least 3 years. Among these the median duration of work was 12.3 years.

EXPOSURE VARIABLE AND DATA ANALYSIS

Individual information on employment periods and work areas was used as a proxy for true exposure information. Information on work was available only at the level of the main departments. Thus, the furnace workers at, for example, the old ferrosilicon furnaces in these plants could not be differentiated from the manganese furnace workers. But these furnace workers probably constitute only a small proportion of all furnace workers.

Most of the methods of data analyses used in this study have been presented in detail elsewhere. ${ }^{12}$ Summarised, SIRs (95\% CIs) were calculated by use of national male 5 year age specific cancer rates for each year from 1953 to 1991 . Rate ratios (RRs) from internal comparisons of rates were calculated with Poisson regression analysis. The Epicure program package was used for both the external (national) and internal (Poisson regression) comparisons of cancer rates. ${ }^{13}$ In this study we also performed analyses of incidence of cancer categorised by employment status (active and inactive person-time) ${ }^{14}$ Active person-time was defined as the employment period from the start of follow up until the end of last employment (including periods off work before that time). Due to inaccurate dates of ending employment, 0.1 year was added to those dates. The remaining part of the observation period was defined as inactive person-time.

A distinction between short and long term employment (or work) was made at 3 years. Two main groups were defined from the cohort: ever furnace workers (furnace workers) and other blue collar workers who never had been furnace workers (non-furnace workers). The non-furnace workers comprised mechanics, electricians, transport workers, raw material workers, packers, and building and construction workers. Individual smoking data were available only for 109 men $(19 \%)$ of those who were registered with a cancer. Thus, the analyses of cancer incidence could not be adjusted for individual smoking habits.

\section{Results}

A total of 607 cases of cancer were observed in 575 men (SIR 1.02, table 1). The cancer incidence was almost the same if the observation ended after the first case of cancer (SIR 1.01). The overall cancer incidence was significantly increased among men first employed before 
Table 1 Observed (Obs) and expected (Exp) numbers of all cancers 1953-91 among 6363 male employees in four FeMn/SiMn plants

\begin{tabular}{|c|c|c|c|c|}
\hline & Obs & $\operatorname{Exp}$ & $S I R$ & $95 \% C I$ \\
\hline Total & 607 & 595.79 & 1.02 & 0.94 to 1.10 \\
\hline \multicolumn{5}{|c|}{ Year of first employment: } \\
\hline $1933-52$ & 382 & 334.53 & 1.14 & 1.03 to 1.26 \\
\hline 1933-59 & 98 & 119.01 & 0.82 & 0.67 to 1.00 \\
\hline $1960-69$ & 74 & 90.87 & 0.81 & 0.64 to 1.02 \\
\hline $1970-91$ & 53 & 51.35 & 1.03 & 0.77 to 1.35 \\
\hline \multicolumn{5}{|c|}{ Year of diagnosis of cancer: } \\
\hline $1953-59$ & 14 & 20.03 & 0.70 & 0.38 to 1.17 \\
\hline $1960-69$ & 76 & 67.18 & 1.13 & 0.89 to 1.42 \\
\hline $1970-79$ & 147 & 154.74 & 0.95 & 0.81 to 1.12 \\
\hline $1980-91$ & 370 & 353.87 & 1.05 & 0.94 to 1.16 \\
\hline \multicolumn{5}{|c|}{ Duration of employment (y): } \\
\hline$<3$ & 171 & 171.26 & 1.00 & 0.86 to 1.16 \\
\hline $3-9$ & 137 & 150.41 & 0.91 & 0.77 to 1.08 \\
\hline $10-19$ & 114 & 115.25 & 0.99 & 0.82 to 1.19 \\
\hline$\geqslant 20$ & 185 & 158.85 & 1.16 & 1.01 to 1.35 \\
\hline
\end{tabular}

1953, and among men with duration of total employment $\geqslant 20$ years.

The incidence of total cancer and of various sites of cancer among furnace and non-furnace workers is shown in table 2. Among the 3122 furnace workers an increased incidence of cancer was found for nose and accessory sinuses, and for other and unspecified sites. Three of the four cases of sinonasal cancers occurred among men employed first before 1953 (SIR $6.72,95 \%$ CI 1.39 to 19.6$)$. They were all long term furnace workers (SIR 6.51, 95\% CI 1.77 to 16.7). The incidence of lung cancer was not significantly increased and there was no case of malignant mesothelioma among the furnace workers. An increased incidence of all cancers was found for furnace work of $\geqslant 20$ years (SIR $1.39,95 \%$ CI 1.07 to 1.76$)$. Among the 2427 non-furnace workers an increased incidence was found for cancer of the pancreas, larynx, and pleura. The incidence of neither lung cancer nor total cancer was increased in this group. Further analyses showed that the SIRs for cancer of the pancreas, larynx, and pleura were significantly increased only among the short term workers (SIRs 2.77 (six cases), 5.67 (five cases), and 13.17 (three cases), respectively). Three of the five cases of malignant mesothelioma occurred among 1000 mechanics in this group (SIR $10.77,95 \%$ CI 2.22 to 31.5 ), and all of these cases occurred $\geqslant 30$ years after first employment as a mechanic (SIR 18.55, 95\% CI 3.83 to 54.22 ). The incidence of lung cancer among the mechanics was, however, not increased (SIR 1.12, 95\% CI 0.56 to 2.00 (11 cases)).

Table 3 presents internal comparisons of the rates of all cancers by duration of furnace and non-furnace work separately. Among the 3122 furnace workers significantly increased trend slopes were found, with and without application of various lags. The highest trend slope was found with a lag of 20 years (RR 1.03 /work-year). In this analysis an RR of 2.36 was found for furnace work of $\geqslant 20$ years compared with furnace work of $<3$ years. The corresponding SIR value was 1.96 (95\% CI 1.24 to 2.94$)$. Among the 2427 non-furnace workers positive but not significantly increased trend slopes were found with application of lags of 10 and 20 years whereas no trend was found with unlagged analyses. However, significantly increased trend slopes of 1.02 (95\% CI 1.00 to 1.05 ) and 1.03 (95\% CI 1.00 to 1.07$)$ were found when lags of 25 and 30 years, respectively, were applied. For the furnace workers the trend slope did not increase when a lag of 25 years was applied (trend slope 1.03, 95\% CI 1.00 to 1.06 ), but an analysis lagged 30 years could not be performed with the same categories due to lack of cases.

The presented trend slopes and RRs were not adjusted for employment as it seems unclear in this situation if employment is only a confounder or also an intermediate variable. ${ }^{15}$ However, we also performed regression analyses with adjustment for employment. This did not change any of the trend slopes for duration of furnace work or non-furnace work with lags of 10 or 20 years. But a slightly positive trend slope of 1.01 was then found for non-furnace work analysed without lag. All the trend slopes for non-furnace work were found to be significantly increased.

The positive association between duration of furnace work and the incidence of all cancers

Table 2 Observed (Obs) and expected (Exp) numbers of various cancers in furnace and non-furnace workers in four $\mathrm{FeM} / \mathrm{SiMn}$ plants

\begin{tabular}{|c|c|c|c|c|c|c|c|c|}
\hline \multirow[b]{2}{*}{ Cancer site (ICD-7) } & \multicolumn{4}{|c|}{ Furnace workers $(n=3122)$} & \multicolumn{4}{|c|}{ Non-furnace workers $(n=2427)$} \\
\hline & $\mathrm{Obs}$ & $\operatorname{Exp}$ & $S I R$ & $95 \% C I$ & $O b s$ & $\operatorname{Exp}$ & SIR & $95 \% C I$ \\
\hline Oesophagus (150) & 1 & 3.37 & 0.30 & 0.01 to 1.65 & 3 & 2.69 & 1.11 & 0.23 to 3.26 \\
\hline Stomach (151) & 23 & 23.27 & 0.99 & 0.63 to 1.48 & 13 & 18.55 & 0.70 & 0.37 to 1.20 \\
\hline Colon (153) & 24 & 21.78 & 1.10 & 0.71 to 1.64 & 19 & 17.27 & 1.10 & 0.66 to 1.72 \\
\hline Rectum (154) & 16 & 14.79 & 1.08 & 0.62 to 1.76 & 16 & 11.67 & 1.37 & 0.78 to 2.23 \\
\hline Pancreas (157) & 10 & 9.99 & 1.00 & 0.48 to 1.84 & 15 & 7.86 & 1.91 & 1.07 to 3.15 \\
\hline Nose, accessory sinuses (160) & 4 & 0.95 & 4.23 & 1.15 to 10.8 & 0 & 0.75 & 0.00 & 0.00 to 4.90 \\
\hline Larynx (161) & 6 & 3.91 & 1.53 & 0.56 to 3.34 & 8 & 3.07 & 2.60 & 1.12 to 5.13 \\
\hline Trachea, bronchus, lung (162) & 41 & 37.30 & 1.10 & 0.79 to 1.49 & 28 & 29.18 & 0.96 & 0.64 to 1.39 \\
\hline Pleura (163) & 0 & 1.01 & 0.00 & 0.00 to 3.65 & 5 & 0.79 & 6.29 & 2.04 to 14.7 \\
\hline Prostate (177) & 46 & 44.63 & 1.03 & 0.75 to 1.37 & 35 & 34.88 & 1.00 & 0.70 to 1.40 \\
\hline Testis (178) & 4 & 5.29 & 0.76 & 0.21 to 1.93 & 1 & 4.27 & 0.23 & 0.01 to 1.31 \\
\hline Kidney, ureter (180) & 7 & 10.60 & 0.66 & 0.27 to 1.36 & 8 & 8.33 & 0.96 & 0.41 to 1.89 \\
\hline Urinary bladder (181) & 17 & 19.33 & 0.88 & 0.51 to 1.41 & 9 & 15.21 & 0.59 & 0.27 to 1.12 \\
\hline Malignant melanoma (190) & 11 & 10.52 & 1.05 & 0.52 to 1.87 & 15 & 8.45 & 1.77 & 0.99 to 2.93 \\
\hline Skin (191; excluding basal cell carcinoma) & 11 & 7.75 & 1.42 & 0.71 to 2.54 & 2 & 6.22 & 0.32 & 0.04 to 1.16 \\
\hline Nervous system (193) & 9 & 9.18 & 0.98 & 0.45 to 1.86 & 6 & 7.30 & 0.82 & 0.30 to 1.79 \\
\hline Other, unspecified sites (199) & 20 & 10.82 & 1.85 & 1.13 to 2.85 & 8 & 8.56 & 0.93 & 0.40 to 1.84 \\
\hline Lymphoma (200-202) & 12 & 10.65 & 1.13 & 0.58 to 1.97 & 7 & 8.46 & 0.83 & 0.33 to 1.70 \\
\hline Multiple myeloma (203) & 2 & 4.90 & 0.41 & 0.05 to 1.47 & 4 & 3.86 & 1.04 & 0.28 to 2.65 \\
\hline Leukaemia (204) & 7 & 6.98 & 1.00 & 0.40 to 2.07 & 3 & 5.54 & 0.54 & 0.11 to 1.58 \\
\hline All sites (140-209) & 291 & 279.73 & 1.04 & 0.93 to 1.17 & 222 & 220.99 & 1.00 & 0.88 to 1.15 \\
\hline
\end{tabular}


Table 3 Observed (Obs) numbers of all cancers with RRs by duration of work and lag intervals among 3122 furnace workers and 2427 non-furnace workers

\begin{tabular}{|c|c|c|c|c|c|c|c|c|c|}
\hline & \multicolumn{3}{|c|}{ No lag } & \multicolumn{3}{|c|}{ Lag $10 y$} & \multicolumn{3}{|c|}{ Lag $20 y$} \\
\hline & $\mathrm{Obs}$ & $R R^{\star}$ & $95 \% C I$ & $\mathrm{Obs}$ & $R R$ & $95 \% C I$ & $O b s$ & $R R$ & $95 \% C I$ \\
\hline \multicolumn{10}{|c|}{ Duration of furnace work (y): } \\
\hline$<3$ & 86 & 1.00 & - & 113 & 1.00 & - & 158 & 1.00 & - \\
\hline $3-9$ & 78 & 1.15 & 0.84 to 1.57 & 68 & 1.09 & 0.79 to 1.51 & 70 & 1.44 & 1.04 to 1.99 \\
\hline $10-19$ & 60 & 1.20 & 0.86 to 1.68 & 67 & 1.67 & 1.20 to 2.34 & 40 & 1.32 & 0.88 to 1.97 \\
\hline$\geqslant 20$ & 67 & 1.54 & 1.10 to 2.15 & 43 & 1.49 & 1.00 to 2.21 & 23 & 2.36 & 1.42 to 3.92 \\
\hline Trend slope & & 1.02 & 1.00 to 1.03 & & 1.02 & 1.01 to 1.03 & & 1.03 & 1.01 to 1.05 \\
\hline \multicolumn{10}{|c|}{ Duration of non-furnace work (y): } \\
\hline$<3$ & 66 & 1.00 & - & 77 & 1.00 & - & 109 & 1.00 & - \\
\hline $3-9$ & 44 & 0.80 & 0.55 to 1.18 & 50 & 1.00 & 0.69 to 1.46 & 45 & 1.06 & 0.72 to 1.57 \\
\hline $10-19$ & 46 & 1.10 & 0.75 to 1.62 & 44 & 1.28 & 0.86 to 1.90 & 42 & 1.19 & 0.79 to 1.79 \\
\hline$\geqslant 20$ & 66 & 0.99 & 0.70 to 1.42 & 51 & 1.15 & 0.77 to 1.71 & 26 & 1.35 & 0.82 to 2.22 \\
\hline Trend slope & & 1.00 & 0.99 to 1.01 & & 1.01 & 0.99 to 1.02 & & 1.02 & 0.99 to 1.04 \\
\hline
\end{tabular}

$\star$ RRs adjusted for age $(<40,40-49,50-59,60-69,70-79, \geqslant 80$ years $)$, calendar time $(1953-59,1960-69,1970-79,1980-91)$, and duration of follow up $(<10,10-19,20-29, \geqslant 30$ years $)$.

$\dagger R R /$ work-year.

was further examined with analyses of the specific sites of cancer. Table 4 shows the incidence of sites with $\geqslant 10$ observed cases among the furnace workers, categorised by duration of furnace work and analysed with a lag of 20 years. For colon, rectum, lung, prostate, skin (ICD-190 and 191), other and unspecified sites, and lymphoma the highest SIR values were found for the highest category of duration of furnace work. The two most numerous sites, lung and prostate cancers, were further analysed with Poisson regression analysis with a lag of 20 years for duration of furnace work. Adjusted for age, calendar time, and duration of follow up a RR of 1.05 (95\% CI 0.99 to 1.11)/work-year was found for lung cancer, and an RR of 1.04 (95\% CI 0.99 to 1.08) was found for prostate cancer. For these cancers combined (adjusted by the same variables) an RR of 1.04 (95\% CI 1.00 to 1.08)/work-year was found. Internal modelling of all other cancers (without lung and prostate cancer) adjusted in the same way showed an RR of 1.03 (95\% CI 1.00 to 1.06)/work-year of furnace work when a lag of 20 years was applied in the analyses.

With respect to previous results we also examined if there was any indication of a reduced risk of cancer associated with work exposures. ${ }^{10}$ We expected that a potential protective effect would be related, with some latency, to the period of exposure. We therefore studied how the cancer incidence changed during time from the start of active service. In these analyses workers first em- ployed before 1953 were excluded as the cancer incidence was not known for all of the employment period. During the first 5 years of employment the overall cancer incidence was close to the expected value both in the remaining group of 2375 furnace workers (SIR $0.99,95 \%$ CI 0.43 to 1.95 ) and in the 1676 non-furnace workers (SIR 1.06, 95\% CI 0.39 to 2.30 ). After the first 5 years of active service the cancer incidence was slightly lower among the furnace workers (SIR 0.84, 95\% CI 0.49 to 1.34 ) but decreased markedly among the non-furnace workers for the person-years of all the remaining period of active employment (SIR 0.24, 95\% CI 0.07 to 0.61 ). In this period of non-furnace work four cancers were observed against 16.75 expected. After the end of employment the overall cancer incidence was close to the expected level both among all furnace workers (SIR 0.97, 95\% CI 0.81 to 1.16) and among all non-furnace workers (SIR $0.91,95 \%$ CI 0.71 to 1.16 ). Analyses of the incidence of all cancers showed for short term furnace and non-furnace work SIRs of $0.84(95 \%$ CI 0.62 to 1.11$)$ and 1.00 (95\% CI 0.68 to 1.41 ), respectively. For long term furnace work an SIR of 1.02 (95\% CI 0.83 to 1.25) was found whereas a decreased SIR of 0.70 (95\% CI 0.51 to 0.95 ) was found for long term non-furnace work. There was also a low rate of lung cancer (SIR 0.96) in the total group of non-furnace workers (also including those first employed from 1933) even if the increased incidence of malignant mesothelioma (SIR 6.29) and of cancer of

Table 4 Observed (Obs) cases of selected cancers with SIRs among 3122 male furnace workers in four FeMn/SiMn plants by duration of work lagged 20 years

\begin{tabular}{|c|c|c|c|c|c|c|c|c|c|}
\hline \multirow[b]{2}{*}{ Cancer site (ICD-7) } & \multicolumn{9}{|c|}{ Duration of work } \\
\hline & $\begin{array}{l}<3 y \\
\text { Obs }\end{array}$ & SIR & $95 \% C I$ & $\begin{array}{l}3-9 y \\
O b s\end{array}$ & $S I R$ & $95 \% C I$ & $\begin{array}{l}\geqslant 10 y \\
\mathrm{Obs}\end{array}$ & $S I R$ & $95 \% C I$ \\
\hline Stomach (151) & 15 & 0.97 & 0.54 to 1.61 & 5 & 1.11 & 0.36 to 2.59 & 3 & 0.89 & 0.18 to 2.61 \\
\hline Colon (153) & 11 & 0.85 & 0.42 to 1.52 & 6 & 1.25 & 0.46 to 2.72 & 7 & 1.75 & 0.70 to 3.60 \\
\hline Rectum (154) & 9 & 1.03 & 0.47 to 1.95 & 3 & 0.90 & 0.19 to 2.63 & 4 & 1.47 & 0.40 to 3.76 \\
\hline Pancreas (157) & 4 & 0.66 & 0.18 to 1.68 & 5 & 2.31 & 0.75 to 5.39 & 1 & 0.57 & 0.01 to 3.20 \\
\hline Trachea, bronchus, lung (162) & 22 & 0.98 & 0.61 to 1.48 & 7 & 0.85 & 0.34 to 1.75 & 12 & 1.85 & 0.95 to 3.23 \\
\hline Prostate (177) & 18 & 0.75 & 0.44 to 1.18 & 12 & 1.14 & 0.59 to 1.99 & 16 & 1.60 & 0.92 to 2.60 \\
\hline Urinary bladder (181) & 10 & 0.91 & 0.44 to 1.67 & 5 & 1.12 & 0.36 to 2.61 & 2 & 0.52 & 0.06 to 1.89 \\
\hline Malignant melanoma (190) & 8 & 1.06 & 0.46 to 2.09 & 1 & 0.54 & 0.01 to 3.00 & 2 & 1.78 & 0.22 to 6.44 \\
\hline Skin (191; excluding basal cell carcinoma) & 6 & 1.41 & 0.52 to 3.08 & 2 & 1.09 & 0.13 to 3.94 & 3 & 1.79 & 0.37 to 5.23 \\
\hline Other, unspecified sites (199) & 12 & 1.80 & 0.93 to 3.14 & 4 & 1.75 & 0.48 to 4.48 & 4 & 2.17 & 0.59 to 5.56 \\
\hline Lymphoma (200-202) & 7 & 0.94 & 0.38 to 1.94 & 2 & 1.06 & 0.13 to 3.84 & 3 & 2.24 & 0.46 to 6.54 \\
\hline All sites (140-209) & 159 & 0.92 & 0.78 to 1.07 & 69 & 1.17 & 0.91 to 1.48 & 63 & 1.33 & 1.02 to 1.70 \\
\hline
\end{tabular}


the larynx (SIR 2.60) might indicate considerable exposure to asbestos as well as an increased prevalence of smoking. ${ }^{36}$ For all person-time of active service a lung cancer SIR of 0.31 (95\% CI 0.04 to 1.11 , two cases) was found among these workers. Among the furnace workers the corresponding lung cancer SIR was $0.62(95 \%$ CI 0.17 to $1.58)$.

\section{Discussion}

The main findings from this study are the positive associations between duration of furnace work and the incidence of all cancers, and the decreasing incidence of all cancers in the period of active non-furnace work. Weaker positive associations between duration of nonfurnace work and the incidence of all cancers were also found.

Although workers in these plants have been exposed to a mixture of gases and dusts, the characteristic for this cohort is the exposure to manganese which is assumed to be a major exposure factor to both the furnace and non-furnace workers. Although it cannot be documented, we suggest that the furnace workers have the highest exposure to manganese of these groups, but the composition of the manganese compounds and the exposure to other agents may vary between the groups. The concentrations of manganese in blood or urine have not been studied in this cohort. However, an increased biological concentration of manganese seems very likely as this has been shown among workers in two Italian ferroalloy plants and in other workers exposed to manganese. ${ }^{17-21}$

Manganese is a ubiquitous element in nature and exists in 11 oxidation states, from -3 to $+7 .^{22}$ Excessive exposure to manganese is mainly work related. In humans manganese is an essential element in many proteins and enzymes - for example, the antioxidant manganese superoxide dismutase (MnSOD). ${ }^{23}$ The MnSOD accelerates the dismutation of the toxic superoxide radical to hydrogen peroxide and molecular oxygen, ${ }^{21}$ and has been shown to play an important part in preventing the development of cancer. ${ }^{24}$ A significantly higher activity of erythrocyte superoxide dismutase and higher concentrations of plasma manganese and malondialdehyde (a product of lipid peroxidation) have been found in workers exposed to manganese compared with referents. ${ }^{21}$ An increased number of white blood cells found among workers exposed to manganese compared with non-exposed workers in two studies might indicate an effect of manganese on the immunological system. ${ }^{18}{ }^{25}$ These results may suggest that exposure to manganese plays a part in preventing the development of cancer.

A possible role of manganese in prevention of cancer has been suggested from a few human and animal studies. In a Finnish study a linear negative association was found between the cancer incidence in 179 parishes and the amount of manganese in cultivated soil from the parishes. ${ }^{10}$ In animal studies it has been found that manganese inhibited sarcoma in- duction if it was injected together with tumorigenic nickel subsulphide $\left(\mathrm{Ni}_{3} \mathrm{~S}_{2}\right)$ or benzo[a]pyrene but not dimethylbenz[a]anthracene in rats. ${ }^{26-29}$ In one of the studies it was shown that the proportion of rats with a sarcoma within 2 years after injection of $\mathrm{Ni}_{3} \mathrm{~S}_{2}$ plus manganese was $7 \%$ versus $77 \%$ in rats that received only $\mathrm{Ni}_{3} \mathrm{~S}_{2} .{ }^{27}$ In a later study it was found that manganese prevented the depression of natural killer cell activity of rat peripheral blood mononuclear cells produced by nickel alone. ${ }^{28}$

A few studies exist in which an increased risk of cancer associated with exposure to manganese are indicated. In a population study in a Scottish town a positive but non-significant association was found between manganese pollution from iron foundries and the standardised mortality ratios (SMRs) for lung cancer in various residential zones in the surroundings. ${ }^{8}$ However, significant associations were simultaneously found for iron and copper. In a study from Japan a higher incidence and mortality from prostate cancer was found in districts with a history of manganese mining than in the remaining districts in that region. ${ }^{9}$ In experimental studies some manganese compounds have been mutagenic in bacteria and yeast cells. In mouse mammary carcinoma cells, $\mathrm{Mn}$ (II) and $\mathrm{Mn}$ (VII) induced chromosomal breaks. ${ }^{6}$ In animal studies manganous acetylacetonate induced injection site tumours in rats and mice, but manganese powder or manganese dioxide did not. ${ }^{630}$

The association between duration of furnace work in the $\mathrm{FeMn} / \mathrm{SiMn}$ plants and the incidence of all cancers may indicate exposure to one or several agents with carcinogenic effects in various organs like the lung, colon, and prostate. Exposure to asbestos and crystalline silica (in SiMn manufacturing) may have increased the rates of lung cancer, but the lack of cases of malignant mesothelioma among the furnace workers indicate a low level of exposure to asbestos in this group. In a corresponding cohort of workers in eight ferrosilicon (FeSi) and silicon metal (Si-met) producing plants an increased total cancer SIR of 1.36 for furnace work of $10-19$ years was found. ${ }^{12}$ These workers were not exposed to manganese. Thus, exposure factors or other conditions in common for these two groups of furnace workers may have contributed to the association between FeMn/SiMn furnace work and the incidence of all cancers. However, an effect of manganese on these results cannot be ruled out. The positive trend between the prostate and lung cancer rates and the duration of furnace work supports the previous suggestion of an association between these two cancer sites and exposure to manganese. ${ }^{89}$ However, the positive associations with all other cancers indicate that the association is not limited to lung and prostate cancer. We suggest that the incidence of several cancers may be increased by one or more exposure factors in the environment of furnace work. The role of exposure to manganese on these results seems unclear. 
The present results indicate an association between sinonasal cancers and exposures in $\mathrm{FeMn} / \mathrm{SiMn}$ furnace work. Previous studies have shown increased risks of sinonasal cancers among furnace and foundry workers (mainly in steel works) in England and Wales, ${ }^{31}$ among men in all areas of the basic metal industries (mainly iron and steel industries) in Denmark, ${ }^{32}$ and among metal workers in Italy. ${ }^{33}$ No exposures to particular metals were suspected in these studies which mainly comprised iron and steel workers. Previous studies have shown an increased risk of exposure to chromium and nickel compounds. ${ }^{33}$ As far as we know, exposure to manganese has not previously been associated with sinonasal cancers. The cancers may also be associated with other unknown work exposures in common with the iron foundries and steel works or have a major contribution from smoking. ${ }^{34}$

The low cancer incidence during persontime of active service among the FeMn/SiMn non-furnace workers may have occurred by chance, but it is not a healthy worker effect as the cancer incidence during the first 5 years of active service was close to the expected level. The results may be explained by an exposure during the employment period associated with cancer prevention or suppressed development of cancer. We did not find similar results in the two corresponding groups of $\mathrm{FeSi} / \mathrm{Si}$-met furnace and non-furnace workers who had been exposed to a similar work environment apart from manganese. Due to lack of real exposure data, any causal factors could not be identified.

Due to lack of data the results were not adjusted for smoking habits, but we examined the prevalence of smoking among the men presently employed in three of the FeMn/SiMn plants in 1989-90. The median proportion of smokers in 5 year birth cohorts among men born in 1940-74 was 0.60 for the furnace workers and 0.45 for the six groups of non-furnace workers. The corresponding value for the general Norwegian population was 0.40 at that time. ${ }^{35}$ Thus, the low incidence of lung cancer during the person-time of active employment in non-furnace work can probably not be explained by a low proportion of smokers. No information was available for other lifestyle factors.

In summary, significantly increasing RRs of all cancers by increasing duration of work $(2 \%-3 \% /$ work-year) were found among the furnace workers whereas weaker but positive associations were found among the nonfurnace workers. However, the incidence of all cancers among the non-furnace workers decreased significantly during the employment period. Due to lack of real exposure data this study cannot identify any causal factors for either of the results. As these workers were exposed to manganese compounds, future studies should focus on the role of manganese in cancer development.

This project has been supported by grants from the Work Environment Fund of the Confederation of Norwegian Business and
Industry (NHO). We are grateful to the staff at the Cancer RegIndustry (NHO). We are grateful to the staff at the Cancer Reg-
istry of Norway for help with identification problems, linking of the cohort and compilation of the national cancer rates, and to Ole Tormod Fure at the Safety, Health and Environmental Secco-operation with participating plants and the financial support.

1 Hobbesland Å, Kjuus H, Thelle DS. A study of mortality among 14730 male workers in 12 Norwegian ferroalloy plants: cohort characteristics and the main causes of death. Occup Environ Med 1996;53:540-6.

2 Kjuus $\mathrm{H}$, Andersen $\mathrm{A}$, Langård $\mathrm{S}$, et al. Cancer incidence among workers in the Norwegian ferroalloy industry. $\mathrm{Br} \mathcal{F}$ Ind Med 1986;43:227-36.

3 Hammond EC, Selikoff IJ, Seidman H. Asbestos exposure, cigarette smoking, and death rates. Ann NY Acad Sci 1979;300:473-90

4 Silica, evaluation. In: Silica, some silicates, coal dust and para-aramid fibrils. IARC Monogr Eval Carcinog Risks Hum 1997;68:210-1.

5 Boffetta P. Carcinogenicity of trace elements with reference to evaluations made by the International Agency for Research on Cancer. Scand $\mathcal{f}$ Work Environ Health 1993;19(suppl 1):67-70.

6 Magos L. Epidemiological and experimental aspects of metal carcinogenesis: physicochemical properties, kinetics, and the active species. Environ Health Perspect 1991;95: $157-89$.

7 Lauwerys RR. Metals: epidemiological and experimental evidence for carcinogenicity. Arch Toxicol Suppl 1989;13: $21-7$.

8 Smith GH, Williams FLR, Lloyd OLL. Respiratory cancer and air pollution from iron foundries in a Scottish town: an epidemiological and environmental study. $\mathrm{Br} 7$ Ind Med 987;44:795-802.

9 Nakata S, Sato J, Imai K, et al. Epidemiological characteristics of prostate cancer in Gunma prefecture, Japan. Int $\mathcal{F}$ Urol 1995;2:191-7.

10 Marjanen $\mathrm{H}$. Possible causal relationship between the easily soluble amount of manganese on arable mineral soil and susceptibility to cancer in Finland. Ann Agric Fenn 1969;8 326-34.

11 Hobbesland Å, Kjuus H, Thelle DS. Mortality from cardiovascular diseases and sudden death in ferroalloy plants. Scand $\mathcal{f}$ Work Environ Health 1997;23:334-41.

12 Hobbesland Å, Kjuus H, Thelle DS. Study of cancer incidence among 8530 male workers in eight Norwegian plants producing ferrosilicon and silicon metal. Оссир Environ Med 1999;56:625-31.

13 Preston DL, Lubin JH, Pierce DA, et al. Epicure. Seattle, Washington: Hirosoft, 1993.

14 Steenland K, Stayner L. The importance of employment status in occupational cohort mortality studies. Epidemiology 1991;2:418-23.

15 Steenland K, Deddens J, Salvan A, et al. Negative bias in exposure-response trends in occupational studies: modeling the healthy worker survivor effect. Am f Epidemiol 1996;143:202-10.

16 Sterling TD, Rosenbaum WL, Weinkam JJ. Risk attribution and tobacco-related deaths. Am F Epidemiol 1993;138:12839.

17 Lucchini R, Selis L, Folli D, et al. Neurobehavioral effects of manganese in workers from a ferroalloy plant after temporary cessation of exposure. Scand 7 Work Environ Health 1995;21:143-9.

18 Lucchini R, Bergamaschi E, Smargiassi A, et al. Motor function, olfactory threshold, and hematological indices in manganese-exposed ferroalloy workers. Environ Res 1997; 73:175-80.

19 Roels H, Lauwerys R, Genet P, et al. Relationship between external and internal parameters of exposure to manganese in workers from a manganese oxide and salt producing plant. Am f Ind Med 1987;11:297-305.

20 Roels HA, Ghyselen P, Buchet JP, et al. Assessment of the permissible exposure level to manganese in workers exposed to manganese dioxide dust. Br F Ind Med 1992;49: 25-34.

21 Yiin S-J, Lin T-H, Shih T-S. Lipid peroxidation in workers exposed to manganese. Scand $\mathcal{F}$ Work Environ Health 1996; 22:381-6.

22 Oberdoerster G, Cherian G. Manganese. In: Clarkson TW, Friberg 1, Nordberg GF, et al, editors. Biological monitoring of toxic metals. New York: Plenum, 1988:283-301.

23 Korc M. Manganese homeostasis in humans and its role in disease states. In: Prasad AS, ed. Essential and toxic trace elements in human health and disease. New York: Alan R Liss, ments in human

$24 \mathrm{Xu} \mathrm{Y,} \mathrm{Krishnan} \mathrm{A,} \mathrm{Wan} \mathrm{XS,} \mathrm{et} \mathrm{al.} \mathrm{Mutations} \mathrm{in} \mathrm{the} \mathrm{promoter}$ reveal a cause for the reduced expression of the human manganese superoxide dismutase gene in cancer cells. Oncogene 1999;18:93-102.

25 Roels H, Lauwerys R, Buchet JP, et al. Epidemiological survey among workers exposed to manganese: effects on lung, central nervous system, and some biological indices. $A m \mathcal{F}$ Ind Med 1987;11:307-27.

26 Sunderman FW, Lau TJ, Cralley LJ. Inhibitory effect of manganese upon muscle tumorigenesis by nickel subsulfide. Cancer Res 1974;34:92-5.

27 Sunderman FW, Kasprzak KS, Lau TJ, et al. Effects of manganese on carcinogenicity and metabolism of nickel gubsulfide. Cancer Res 1976;36:1790-800.

28 Judde JG, Breillout F, Clemenceau C, et al. Inhibition of rat natural killer cell function by carcinogenic nickel compounds: preventive action of manganese. $\mathcal{F}$ Natl Cancer Inst 1987;78:1185-90. 
29 Sunderman FW, McCully KS, Taubman SB, et al. Manganese inhibition of sarcoma induction by benzo[a]pyrene in rats. Carcinogenesis 1980;1:613-20.

30 Kazantzis G. Role of cobalt, iron, lead, manganese, mercury, platinum, selenium, and titanium in carcinogenesis. Environ Health Perspect 1981;40:143-61.

31 Acheson ED, Cowdell RH, Rang EH. Nasal cancer in England and Wales: an occupational survey. $\mathrm{Br} F$ Ind $\mathrm{Med}$ 1981;38:218-24.

32 Olsen JH. Occupational risks of sinonasal cancer in Denmark. Br F Ind Med 1988;45:329-35.
33 Comba P, Barbieri PG, Battista G, et al. Cancer of the nose and paranasal sinuses in the metal industry: a case-control study. Br F Ind Med 1992;49:193-6.

34 Zheng W, McLaughlin JK, Chow W-H, et al. Risk factors for cancers of the nasal cavity and paranasal sinuses among white men in the United States. Am f Epidemiol 1993;138: $965-72$.

35 Rønneberg A, Lund KE, Hafstad A. Lifetime smoking habits among Norwegian men and women born between 1890 and 1974. Int $\mathcal{F}$ Epidemiol 1994;23:267-76.

\section{Vancouver style}

All manuscripts submitted to Occup Environ Med should conform to the uniform requirements for manuscripts submitted to biomedical journals (known as the Vancouver style.)

Occup Environ Med, together with many other international biomedical journals, has agreed to accept articles prepared in accordance with the Vancouver style. The style (described in full in the $\mathcal{F A M A}[1]$ ) is intended to standardise requirements for authors, and is the same as in this issue.

References should be numbered consecutively in the order in which they are first mentioned in the text by Arabic numerals on the line in square brackets on each occasion the reference is cited (Manson[1] confirmed other reports[2][3][4][5]). In future references to papers submitted to Occup Environ Med should include: the names of all authors if there are three or less or, if there are more, the first three followed by et al; the title of journal articles or book chapters; the titles of journals abbreviated according to the style of Index Medicus; and the first and final page numbers of the article or chapter. Titles not in Index Medicus should be given in full.

Examples of common forms of references are:

1 International Committee of Medical Journal Editors. Uniform requirements for manuscripts submitted to biomed journals. $¥ A M A$ 1993;269:2282-6.

2 Soter NA, Wasserman SI, Austen KF. Cold urticaria: release into the circulation of histmaine and eosinophil chemotactic factor of anaphylaxis during cold challenge. N Engl F Med 1976;294:687-90.

3 Weinstein L, Swartz MN. Pathogenic properties of invading micro-organisms. In: Sodeman WA Jr, Sodeman WA, eds. Pathologic physiology, mechanisms of disease. Philadelphia: W B Saunders, 1974:457-72. 